\title{
Harveian Oration 2015: Medicine, science and values - with hindsight and foresight
}

\author{
Author: Mark Walport ${ }^{\mathrm{A}}$
}

Four hundred years ago, the College of Physicians was approaching its first centenary; William Harvey was aged 37 and was rising fast in the medical profession. It was 1615, and King James I was on the throne. Harvey, who had become a fellow of the College in 1607, was appointed to the Lumleian Lectureship, which required that he undertake weekly public dissections. It was 19 years before he would publish his work that transformed our understanding of the movement of blood, De motu cordis.

It was the end of the Renaissance - Harvey was born in a Europe where God reigned supreme as the creator of the universe and the Bible was the source of human values. It was a time of conflict - between church and monarchy about the identity of God's representative on earth, and between divinity and science in the field of cosmology. Galileo was under investigation by the Roman Inquisition for promoting the heliocentric work of Copernicus. In March 1616, they suspended Copernicus's book De revolutionibus orbium coelestium from circulation until it was corrected to prevent his opinion from creeping 'any further to the prejudice of Catholic truth'. And sentencing Galileo in June 1616, they wrote: 'That the sun is the centre of the world and motionless is a proposition which is philosophically absurd and false, and formally heretical, for being explicitly contrary to Holy Scripture.' It was not until 1758 that De revolutionibus was removed from the Index of Prohibited Works.

In so far as William Harvey was troubled by these upheavals, it was through his temporal role as the medical servant of a king, Charles I, rather than because of any conflict between science and religion. Harvey became entangled in the Civil War, a war between the supremacy of the monarch and the ordinary man. He lost some of his key manuscripts to the Civil War but was lucky that he was able to work continuously throughout the turmoil of the first half of the 17th century and to die of natural causes aged 79 in 1657, following a stroke.

Harvey's conflict with his profession had a certain timeless quality to it - he challenged the wisdom and norms of his colleagues. His own clinical practice was ridiculed and threatened by what others saw as his eccentric cardiovascular theories.

Author: ${ }^{\text {A }}$ chief scientific adviser to HM Government and head of the Government Office for Science, London, UK
Nothing changes: at medical school many of us were taught convincingly about the causal role of the vagus and excess acid secretion in the generation of peptic ulceration - and the idea that infection could be the cause of peptic ulcers was beyond the pale, even though bacteria attached to the wall of the stomach were clearly visible to the astute histopathologist. Harvey was an establishment man, but driven by restless curiosity and with the means to indulge this. He had learnt of the valves in veins in the dissecting theatre of Fabricius at Padua and his urge to dissect, and opportunity to vivisect, meant that he had ample opportunity to observe the beating of the heart and the movement of blood - and this culminated in his great work, De motu cordis.

Another contemporary of William Harvey was Francis Bacon, who, born in 1561, was 17 years Harvey's senior. There is evidence from Aubrey's Brief Lives, transcribed in the great biography of Harvey by Sir Geoffrey Keynes, ${ }^{2}$ that Harvey treated Bacon. In 1619, both Bacon and the king suffered from 'attacks of the stone'. Aubrey reported that Bacon '...had a delicate, lively hazel eie. Dr Harvey told me it was like the eie of a viper', and that 'He writes philosophy like a Lord Chancellor'. It is difficult to discern what Harvey meant by this - but it was not a compliment!

Then as now, patients with strong views on the causes and treatment of their condition could come into conflict with their doctors - and we can speculate that Harvey and Bacon did not have the best doctor-patient relationship. Bacon had clear views on the treatment of his gout: 'he first applied a poultice, and then a bath or fomentation, and then a plaster ${ }^{3}$ - whereas Aubrey tells us that Harvey:

would sitt with his Legges bare, if it were Frost, on the leads of Cockaine-House, putt them into a payle of water till he was almost dead with Cold and betake himselfe to his Stove, and so 'twas gonne. ${ }^{2}$

These anecdotes tell us some important things. That even the smartest people are strongly influenced by personal experience and, a corollary, the best physician scientists do not necessarily always practise evidence-based medicine.

Bacon was a natural philosopher who proposed a grand and all-encompassing scheme of investigation. He was also a practical experimentalist. But he appeared to have little time for the type of scientist who is most prized today, the scientist focused on a singular important area of science. 
Evidence for this comes from his criticisms, in the Novum organum, of William Gilbert and his focus on magnetism. Bacon wrote, 'for no-one successfully investigates the nature of a thing taken on its own; the inquiry needs to be enlarged so as to become more general. ${ }^{4}$

Gilbert, physician to Queen Elizabeth I, published his great work, De magnete, ${ }^{5}$ in 1600 , and in the same year became president of this College. The first sentence of this work starts:

Clearer proofs, in the discovery of secrets, and in the investigation of the hidden causes of things, being afforded by trustworthy experiments and by demonstrated arguments, than by the probable guesses and opinions of the ordinary professors of philosophy...

He set out to understand the magnetic properties of the earth by studying the properties of common magnetic materials such as lodestone.

Harvey was, like Gilbert, a highly focused investigator - and the origins of this oration were set out in a trust deed dated 21 June 1656, in which he stated that the occasion should be used for 'an Exhortacion to the ffellowes and members of the said Colledge to search and studdy out the secrett of Nature by way of Experiment'.

There is evidence that Bacon was aware of Harvey's work when he wrote of:

microscopes, lately invented, which (by remarkably increasing the size of the specimens) reveal the hidden, invisible small parts of bodies, and their latent structure and motions. By their means the exact shape and features of the body in the flea, the fly and worms are viewed, as well as colours and motions not previously visible, to our great amazement. ${ }^{6}$

Bacon and Harvey together provide the historical origins of this oration. Bacon founded modern thinking on the philosophy of science and in particular on the relationships between science and human values, which will be the focus of this oration.

\section{Bacon's 'idols'}

In his great work Novum organum or The new organon, ${ }^{6}$ named after and intended to supersede Aristotle's work on logic, the Organon, Bacon set out the key principles for his grand scheme of natural philosophy.

He put forward four groups of 'idols' that shape human thoughts and behaviours. These idols are misconceptions that get in the way of objective analysis and understanding of the world in which we live.

The first are the Idols of the Tribe - imposed upon us by the very nature of our humanity. I paraphrase, in places, the translation of Bacon by Jonathan Bennett:

It is not true that the human senses are the measure of things; for all perceptions - of the senses as well as of the mind-reflect the perceiver rather than the world. The human intellect is like a distorting mirror, which receives light-rays irregularly and so mixes its own nature with the nature of things, which it distorts. ${ }^{4}$

Second are the Idols of the Cave - these are our individual ideas, beliefs and values that we develop from living in our own personal cave. They come from:

our own individual nature, how we have been brought up and how we interact with others, our reading of books and the influence of writers we esteem and admire, differences in how our environment affects us because of differences in our state of mind... So that the human spirit is distributed among individuals in ways that make it variable and completely disorderly-almost a matter of luck. Heraclitus was right: men look for sciences in their own individual lesser worlds, and not in the greater world that they have in common. ${ }^{4}$

Third are the Idols of the Market - these follow the transactions between people, which depend on social structures, values and norms:

Men associate by talking to one another, and the uses of words reflect common folks' ways of thinking. It's amazing how much the intellect is hindered by wrong or poor choices of words. ${ }^{4}$

This is an important topic that I will return to.

And, fourth: the Idols of the Theatre, the consequences of our unthinking acceptance of current dogma and explanations, 'Coming from the fanciful stories told by philosophical theories and from upside-down perverted rules of demonstration, they are openly proclaimed and openly accepted.' For example, that peptic ulcers are caused by vagal overactivity.

These four 'idols' are as important and influential today as they were when Bacon defined them in the 17 th century and I will argue that the impact of science in medicine and society can only be understood and maximised if we take these idols into account in our everyday work.

\section{Subjective and objective worlds}

Another way of thinking about Bacon's idols is to think about subjective and objective worlds, or as Professor Perry put it in his book, Realms of value, the world which man has made for himself and the world which he takes as he finds. ${ }^{7}$ The subjective world of humans is the world of thoughts, feelings and passions, in which we find Bacon's idols of the tribe and of the cave. Acting collectively, it is how we organise our societies, our politics, our art, our education and our religions. This world is the domain of politics and of scholars of the social sciences and the humanities. The objective world, the world we take as we find, is the universe that can be described by scientific observation and experimentation, from the macro (the behaviour of galaxies, stars and planets), to the micro (atoms and atomic particles, chemical elements, the biology of cells, organs and organisms). This is the world of the natural scientist. And so, an alien in another galaxy would perceive the universe through its own form of perceptions and would make its own world, barely conceivable to us. However, an alien natural scientist would uncover the same facts about the nuclear fusion reactions and fundamental particles in its own nearest star as we are uncovering in the sun.

My PhD supervisor, Sir Peter Lachmann, has framed the distinction between the subjective and the objective in a different way, by considering whether questions are 'pollable' or 'non-pollable'; that is, whether a question can be answered in principle by a vote (a pollable question), or whether the question has a right answer that is independent of individual preferences and opinions (a non-pollable question). This distinction can be easily illustrated by a couple of examples. It is a non-pollable question as to whether there is an anthropogenic contribution to climate change. There is a correct answer to 
this question and your opinion or mine is ultimately irrelevant. The fact that there may be uncertainties about the scale and the nature of the contribution does not change the basic nature of the question. In contrast, it is a pollable question as to whether nuclear energy is an acceptable solution to providing lowcarbon power, and I will return to this later.

The natural sciences are directed towards answering nonpollable questions. But pollable questions are also in the domain of the sciences. The tools of the social sciences are important for analysing pollable questions, though they cannot provide singular answers. So understanding how people think about the risks and benefits of nuclear power is an important question for the social sciences. Indeed there are many pollable questions that arise as a result of our pursuit of the natural sciences and our ability to harness the 'secretts of nature' for benefit and for harm.

\section{Science and human values}

Another way of looking at the subjective versus the objective is through the lens of 'values'. As Stroud put it in his Tanner Lecture: ${ }^{8}$

On the 'subjectivist' view, matters of value - of the goodness or badness, the beauty or worth, of a thing or action - are not in this way anything to be found among the facts of the world at all. ${ }^{8}$

A little later he says:

It is, rather, that in the realm of values there is simply no 'objective' truth to be known. The world in itself is just what it is; it is simply there. It is the totality of facts, and it is value free. ${ }^{8}$

But that does not of course diminish the importance of values and it is a characteristic of humans, probably a unique characteristic, at least in so far as we are conscious of them, that we are strongly driven by values. My thesis tonight is that if we are to achieve the maximum benefit from science and, in particular from advances in the medical sciences, then we need to focus on the interactions between science and human values. And we need to start by recognising where science meets values and distinguishing arguments about science from arguments about values.

Values are usually equated with moral values, but moral values are only a subset of human values. Perry ${ }^{7}$ classified 'realms of values' as: moral, political, legal, economic, customary, scientific or intellectual, and aesthetic. And human values are not universal - as human cultures vary in time and geography, so also do associated values and systems of values. Bacon was wrong when he described the idols of the tribe because whilst humans are a single species, we are by no means a single tribe.

The reality is that we each belong to many tribes and assume different personae and identities as part of the membership rites, obligations and values of each tribe, be it in my case the tribe of doctors, the tribe of scientists, the tribe of Whitehall officials, the tribe of my family, the tribe of birdwatchers and the tribe of collectors of past Harveian orations. And the corollary of identity is identification - to belong to a tribe requires acceptance by other members of that tribe, and at least a degree of conformity to the obligations, values and rituals of that tribe. And with tribes goes tribalism, and conflict between tribes, tribes of football supporters, local gangs, cities, regions and states. Societies are not singular - they are jigsaws of tribes with differing values.

So if we are to practise medicine effectively, we must bring together science, the 'objective', with the 'subjective', the values and experiences of the patients and societies in which we work.

\section{Innovations, values and the perception of risk}

Moving to the present: the human population has grown exponentially so that there are now more than 7 billion humans on the planet. And the vast majority of humans are now living much longer and healthier lives than ever before. Whereas Harvey was the exception in living almost into his ninth decade, many of this audience will achieve this span, and some already have. But this longevity comes at a price. The modes of death of the elderly are frequently preceded by prolonged periods of incapacity.

There were five revolutions that enabled the dramatic expansion of human populations - and a common denominator was that each increased our ability to modify the environment of the planet in our favour, with many consequences for the other species with which we share the earth. The first of these revolutions, which we can only speculate about, was our development of language and social interactions. These enabled us to act cooperatively and, by differentiating our skills, to contribute in complementary ways to create functional communities. The second revolution was our development and use of tools, first stone and subsequently metal. The third was the development of agriculture and sophisticated dwellings to control our supply of food and provide safe environments to protect against the weather and seasons. The fourth was the industrial revolution of the 18th century. This enabled us to harness the energy stored in fossil fuels to power the machinery that has transformed human living conditions. We are now in the full swing of the fifth revolution, the information technology revolution, which is likely to be every bit as significant as each of the preceding revolutions.

The rate of growth in human populations is now slowing. It is an economic and social advantage to have lots of children when child mortality is high, but a disadvantage when mortality is low and the costs of child rearing become high. But 7 billion people, growing towards 9 billion, is still a lot of people. And the burning of fossil fuels that has powered much of the lifestyle change of humans over the last couple of centuries and the other 'footprints' of human populations are leaving permanent marks on the planet, so much so that it is being actively debated whether the earth is entering a new geological era, the Anthropocene. ${ }^{9}$ This will be detectable, long after we are gone as a species, through the imprint that we will have left on geological strata. Put bluntly, the waste from 7 billion humans is altering our environment and that of other species in myriad and largely deleterious ways.

The scientific, engineering and technological advances of the 20 th century brought with them some important changes in the relationship between science and society, leading some to question whether science will be our salvation or our doom. Physics is a paradigm of this - from the heroic discoveries of Rutherford in splitting the atom, to the Manhattan project (the extraordinary destructive forces of nuclear fission in the atomic bomb, or nuclear fusion in the hydrogen bomb), to the prospect 
of limitless clean energy from nuclear power. Are we surprised by people's ambivalence and the differences in attitude between nations to radiation and nuclear power?

Another change is our attitude to risk and danger. Danger has transitioned from something over which we have no control to something that we must minimise at all costs; and when something goes wrong, there is always someone to blame. And this someone has become remote authority, the politician or the large corporation.

So we are caught in a dilemma. On the one hand, if we carry on as we are, the products of our contemporary lifestyles will spoil the planet for our descendants and for other species. On the other hand, there is an enormous mistrust and apprehension about the risks associated with the innovations that will be needed for a sustainable relationship between 9 billion humans, and the fitness of the future environment of the planet for ourselves and other species.

Where does the medical profession and innovation in medicine fit into this complex mix? How can we reconcile innovation in the world of medicine with the values and perceptions of risk in the societies in which we work?

\section{Medical innovations, risks and benefits}

Innovation in medicine starts with a great advantage new treatments are generally seen as a public good. But if only it were so simple. The development of new vaccines, medicines and other treatments is accompanied by important considerations about equity and fairness. For a rare disease, or a disease of the poor, will there be a market - so will a product be developed? If a product is developed, will it be available to all? Who will pay? Who will benefit - only the rich, or the rich and the poor?

A second issue of equity and fairness is the unequal allocation of risks and benefits - what might be termed 'my pain, your gain'. I suffer an adverse effect whilst others benefit from a new drug. Who should I blame if something goes wrong? Who will provide recompense? How much should I be compensated and should the amount of compensation be punitive? Who should be punished? Vaccines provide another example of apparently unequal allocation of risks and benefits - my child receives the vaccine and the attendant risks, your child is not vaccinated but benefits from the 'herd immunity'.

\section{Privacy, autonomy and the information technology revolution}

Moving to a second value-laden area - privacy and autonomy the contract between the physician and their patient has always been based on confidentiality. I will tell you some of my most sensitive secrets because you need these to advise and treat me. In return you will look after me and demonstrate your trustworthiness by not revealing my secrets to anyone outside the circle of healers.

However, in an era of evidence-based medicine, only by sharing information about health and disease, response and lack of response to treatment, effects and side effects, can the evidence be collected to provide the best advice and treatment. So a second tier of sharing of health secrets has developed for the purposes of research, where personal information can be pseudonymised or anonymised. In these circumstances, I will consent to the sharing of my private data in the context of a more extended circle of confidentiality, on the understanding that new knowledge gleaned may benefit others with similar conditions.

But the revolution in information technology is changing the game. It is starting to have a massive impact on the implementation and meaning of privacy and autonomy. Hundreds of millions of people around the world have entrusted businesses, governments and social enterprises of different shapes and sizes with almost every detail about their lives, their preferences, their finances, their geographical location in real time and more. This information is stored on servers in the 'Cloud', a metaphorical name for a physical reality of distributed servers that is only well understood by the most initiated users. Why do we do share all this information? It is because we receive an extraordinary array of useful services - knowledge really is power to each and every one of us. Indeed, when it comes to private and sensitive information, many people entrust this to social networks and other web services in as much or more detail than can be found in their medical records. The information technology revolution is also providing access to new healthcare providers, some of whom may be located in far distant countries. Accelerometers, pulse monitors, oximeters and global positioning system (GPS) technology, attached to wearable devices including shoes, watches and wrist bands, collect and transmit physiological and geolocational information about us to cloud servers. We share our health and location data with the companies that sell us these devices, often without thinking through the potential consequences. These companies and services promise confidentiality, though in the world of social networks, where we share information with friends, the definition of friendship has frequently taken on a new and lax meaning. Do we really know who are the people who have access to our personal information in companies that provide social and health services? Careless handling of personal data, breaches of cybersecurity and the 'mashing' of different data sets can reveal our personal secrets all too easily.

\section{Information technology and medical practice}

But something funny is going on in the profession of medicine with respect to the implementation of advances in information technology. There is no doubt that information technology is transforming medical research and the understanding of the variation between humans in health and disease. Reading a genome of 3.2 billion base pairs or analysing a proteome or metabolome is becoming affordable and scaleable. The UK Biobank project is following 500,000 of us who were aged between 40 and 69 at the age of entry into the study. This study links our health records with detailed physiological and imaging information. The 100,000 Genomes Project will sequence the genomes of 100,000 patients in the NHS. The impact of information technology in research is profound.

But the application of information technology to transform the service provision of our profession of medicine lags far behind the application of technology to other service industries. What is going on?

It comes back to a discussion between science and values on the one hand - and to professional resistance to change on the other; Bacon's idols of the cave and of the theatre. There 
needs to be a much clearer discussion within the medical profession about what information technology can bring to medical practice, and the new opportunities to maintain health as well as to treat illness more effectively. I fear that we as a profession are resisting change and often using concerns about confidentiality as the justification for this resistance.

Do not get me wrong, confidentiality really does matter. And it matters in many areas of our lives. For example, we are protective of our financial as well as our health records. But it is extraordinary how much technology has changed consumer financial services; indeed it is billing as much as the health record that is driving IT advances in healthcare in the USA. Technology can provide solutions to confidentiality as well as creating new challenges. For example, distributed ledger technology, powered by blockchain algorithms, has the potential to transform all aspects of the supply chain of medicine, from keeping medical records to providing assurance that the medicines we prescribe and take are not counterfeit.

\section{Science and values in medical innovation}

This discussion brings us into other areas of medical innovation where personal religious and spiritual values have the potential to come into conflict with science. This is splendidly illustrated by the recent discussions about the introduction of nuclear transfer as an approach to preventing the inheritance of mitochondrial disease.

Last year, in response to the consultation by the Human Fertilisation and Embryology Authority on the draft regulations to permit the use of new treatment techniques to prevent the transmission of serious mitochondrial diseases from mother to child, the Mission and Public Affairs Council of the Church of England wrote:

While supportive, in principle, of both MST [maternal spindle transfer] and PNT [pronuclear transfer], we believe that further research is necessary into the relationship between mtDNA [mitochondrial DNA] and nDNA [nuclear DNA]. Concerns have been raised, for example, with regard to potential mismatches between the mitochondrial and nuclear genome, with varying responses noted from scientists. ${ }^{10}$

And just before the debate in the House of Commons on this issue on 29 January 2015, the Church of England's national adviser on medical ethics was quoted in The Daily Telegraph as saying:

The Archbishops' Council, which monitors this issue, does not feel that there has been sufficient scientific study or informed consultation into the ethics, safety and efficacy of mitochondria transfer. Without a clearer picture of the role mitochondria play in the transfer of hereditary characteristics, the Church does not feel it would be responsible to change the law at this time. ${ }^{11}$

Now I have no problem with those who object to this approach to treatment on religious or other moral grounds - but I do object when they do not state their real reason for objection, hiding behind spurious accusations about the inadequacy of the science. I think it is unlikely that a spokesman for the Royal College of Physicians would have stated that the RCP did not think that the theology was clear.

All too often arguments about science are conflated with arguments about values. And this applies to many innovations outside medicine. Fracking is a particularly interesting example of where discussions about science and engineering have become conflated with discussions about values. The science and engineering questions about fracking are threefold: will the drilling and hydraulic injection of fluids cause seismic tremors? Will the injection of water, sand and chemicals cause contamination of drinking aquifers? And will there be fugitive release of methane gas into the atmosphere that could nullify any advantages of using methane as a fossil fuel compared to coal?

The Royal Academy of Engineering and the Royal Society have addressed these questions in a report. ${ }^{12}$ Their conclusion is that, whilst no drilling technology for fossil fuel is completely safe, good regulation and engineering can minimise these risks to an acceptable level. The protesters on the other hand are protesting about different issues. Some do not like fossil fuel at all, others do not trust large companies and others are concerned about the effects of the drilling on the local amenities of their home and community. And there is another group that does not accept any scientific definition of 'acceptable' risk - because they consider that this is not a matter for scientists but rather for society - and this begs important questions about 'standards' of purity. I will return to this topic in a moment.

This takes us to the role of different players in the resolution of conflicts between the applications of science, engineering and technology, and the differing values of the different individuals and tribes within the population.

In my role as chief scientific adviser to the government, I am quite often told that politicians need to be better educated in science - and this may be true. But it is equally the case that scientists need to be better educated in politics - in particular to understand how policymakers are motivated.

Policymakers, who in democratic societies are ultimately the politicians that we elect, determine the framework for the operation of society. To achieve this they blend evidence, pragmatism and prejudice to legislate, regulate and direct the workings of local and national government. They look through three lenses, the lens of evidence (what do we know about ' $\mathrm{X}$ '?), the lens of practicability (can policy ' $\mathrm{Y}$ ' be delivered in practice?) and the lens of politics (what does my electorate think?). And here there is an important point, recognised by David Hume in the 18th century, that politicians are governed at least as much by passion as by reason. ${ }^{13}$

My last foray into the relationship between science, innovation and values is in relation to our values around purity and hygiene.

\section{Purity and hygiene, hazard and risk}

As we have become healthier, we have become more risk averse. Death is fortunately, for the majority of us, something that is not an everyday encounter. We are becoming a nation of the 'worried well'. And that poses a particular and important set of challenges for medical science - understanding the relationship between environmental exposures and health, the difference between hazard and risk, spotting the signal above the noise. These challenges are compounded by the vastly increased sensitivity of our analytical tools, which means that we can measure infinitesimal amounts of substances as contaminants of the water we drink, the food that we eat and the air that we breathe. When does any of this matter? 
The challenge for politicians has been set out by Mary Douglas in her book of collected essays Risk and blame: 'Disasters that befoul the air and soil and poison the water are generally turned to political account: someone already unpopular is going to be blamed for it. ${ }^{, 14}$

Here I think that the role of the medical scientist is clear. It is to analyse the evidence, define the uncertainties and work out what evidence is needed for clarification.

In my world of Whitehall and the broader policy environment of Europe and beyond, the problems are many: for example the effects and side effects of insecticides and pesticides, environmental oestrogens, air pollution, contamination of beef by horsemeat, and the contamination of drinking water by Cryptosporidium and other micro-organisms.

There are three challenges to providing the best advice to policymakers and to the public. The first is the challenge of communication - and in particular to get across the message that hazard is not the same as risk. The second challenge is the scientific challenge to provide evidence and communicate uncertainty. The third is the challenge for the policy maker, which is how to balance benefits and risks - and how, in the face of uncertainty, to use the precautionary principle to best effect.

\section{Hazard and risk}

Starting with hazard and risk - hazard is not the same as risk. The relationship between hazard and risk is mediated by exposure and vulnerability. The example of a fish, the cleaner wrasse, swimming in the open jaws of a conger eel illustrates this relationship. The risk to the cleaner wrasse is the product of the hazard, the sharp teeth and jaw muscles of the eel, multiplied by its exposure (in this case sitting in the open jaws), multiplied by its vulnerability, which is extremely low, because the cleaner wrasse and the conger eel have co-evolved a symbiotic relationship. So in this case, in the face of a nasty hazard, the risk to the wrasse is minute. The wrasse acts as the oral hygienist for the eel. It gets a meal, the eel has a clean mouth and they both live happily ever after. We, the observers, are uncertain the first time we see the fish in the mouth but by applying scientific method, in this case repeated observation rather than experimentation, we reduce our uncertainty; and this of course is what the scientific method is all about - using observation and experimentation to reduce scientific uncertainty.

The case of the wrasse and the conger eel illustrates the importance of vulnerability in relation to risk - but a commoner problem is the failure to recognise the importance of exposure as a mediator between hazard and risk. However hazardous the hazard, if the exposure is insignificant, so is the risk.

One example that illustrates this is radioactivity, where the hazard is obvious. But there is confusion in public discourse between hazard and risk. Take three major accidents at nuclear power plants, Three Mile Island, Chernobyl and Fukushima. Outside of the power plants, only in the case of Chernobyl is there evidence that the exposure to radiation has caused direct harm to humans. ${ }^{15}$ That took two forms. The first was an excess of thyroid cancer in people who were young when exposed to the radioiodine released from the damaged power plant. Fortunately thyroid cancer is amongst the most treatable of tumours, though fatal in a small proportion of cases. The thyroid has immense powers to trap and concentrate iodine, so the exposure of the thyroid gland to radiation was high, and the young are more vulnerable than older people to radioiodine exposure. The second direct consequence of the radiation was a small excess of leukaemia in the 'liquidators', the people who managed the disaster on the ground, and some of these individuals were exposed to amounts of radiation in excess of 1 sievert. The authors of a detailed review of the impacts of Chernobyl and Fukushima concluded that:

Socioeconomic effects, such as widespread mistrust in nuclear technology as well as nonradiationinduced diseases such as anxiety, depression, or posttraumatic stress are likely to be the most significant effects from both accidents. ${ }^{16}$

One of the great policy challenges facing politicians around the world is decarbonisation of power supplies. Nuclear power could be one of the important solutions. At its heart, it is a simple technology. Controlled nuclear fission generates heat that boils water to generate the steam to drive turbines that provide electricity.

But we need to be very clear how the role and the expertise of the natural scientist differs from the role of the policymaker. Perry put this very clearly:

The role of nuclear physics in war and industry is a topic of cultural science. ...This topic does not belong to physics, because the physicist is concerned with entities that are not of man's making; war and industry are not his affair. When he discusses the latter he changes his role. ${ }^{7}$

And I would argue that scientists and doctors need to be more self-aware when they are acting as advocates rather than as dispassionate communicators of evidence.

This quotation from Ulrich Beck's book, Risk society, ${ }^{17}$ illustrates the challenge to the implementation of nuclear energy and the difference between a scientific and a social conception of risk from human pollutants:

By risks I mean above all radioactivity, which completely evades human perceptive abilities, but also toxins and pollutants in the air, the water and foodstuffs, together with the accompanying short-and long-term effects on plants, animals and people. They induce systemic and often irreversible harm, generally remain invisible, are based on causal interpretations, and thus initially only exist in terms of the (scientific or anti-scientific) knowledge about them. They can thus be changed, magnified, dramatised or minimised within knowledge, and to that extent they are particularly open to social definition and construction. Hence the mass media and the scientific and legal professions in charge of defining risks become key social and political positions.

Compare this with Marvin Goldman, writing in Science, 'It is time to scientifically challenge the old tenet stating that cancer risk is always proportional to dose, no matter how small. ${ }^{18}$

This is just one example and articulation of where the application of science to deal with one of the challenges of the anthropocene era meets human values. However, again and again we see the application of science meeting human values - and I would argue that we have poor and confused discussions because we conflate the scientific discussion with the discussion of values.

\section{Conclusion}

In the 17th century, Harvey could sit apart from national and global conflicts, exploring the 'secrett of nature', and suffering 
inconvenience when some of his papers were stolen during the Civil War. Can and should the physicians and scientists of today do the same? I do not think that this is possible or desirable.

Our world is utterly different from the European world in the time of Harvey. The voice of individuals and tribes from around the whole world can be heard in completely new ways with the immediacy of the Twitter mob. Global communication is essentially instantaneous and we are confronted with a cacophony. All voices are potentially audible; and, equally challenging, there are channels for the wicked to communicate globally in inaudible and encrypted ways.

Can we cope with our own idols of the theatre? The scientific, engineering and technological context of medicine is undergoing a revolution. We are racing into a world where it will be easier and easier to read and to understand those 3.2 billion base pairs that are our collective and individual inheritance. The power of analytical techniques means that our genome sequence can be correlated with RNA and protein expression. Our microbiome has become a tractable subject for study. Wearable and external devices developed from advances in engineering and information technology will integrate new materials with biology and IT. Our location, our physical environment, our activity, and our physiology will be continuously and remotely monitored. Computer-aided diagnostics and machine learning will supplant our own cognitive abilities. Personalised medicine will bring automated diagnosis and prescription. Distributed ledgers will disrupt existing ways of keeping records. Will we fight this revolution or embrace the new opportunities that it will bring?

I believe that we have nothing to fear. Our job is to integrate the objective and the subjective in our care for our patients, to integrate the technical with the human. And exploring the 'secrett of nature' and applying our discoveries will keep us busy for a long time to come.

I also think that there is a larger agenda for the medical profession. Humans find themselves between a rock and a hard place - between the growing impacts of 7 billion humans on the planet and an increasing resistance to the acceptability of innovative solutions. ${ }^{19}$ We must play our part both as individuals and collectively as a profession. We must be clear and explicit when we are talking about science and when we are talking about values. And we should be proud of the value system that we have inherited from Harvey and the other great leaders and innovators of our profession.

We must think about, debate, maintain and evolve the value system that goes with a caring profession - and fight the corner of those values in public; and that takes us to the second part of Harvey's trust deed to the College of Physicians:

and also for the honour of the Profession to continue mutuall love and affeccion amongst themselves without which neither the dignity of the Colledge can bee preserved nor yet particular men receave that benefit by their admission in the Colledge which els they might expect, Ever remembering that Concordia res parvae crescunt, Discordia magnae dilabuntur.

Which is a quote from the Roman historian Sallust: 'With harmony small things increase, with discord the greatest come to nothing.'

And so to dinner...

\section{References}

1 Finocchiaro MA. The Galileo affair: A documentary history. Berkeley and Los Angeles: University of California Press, 1989.

2 Keynes G. The life of William Harvey, Oxford: Clarendon Press, 1966.

3 Bacon F, Verulam Lord, Alban Viscount St. Sylva sylvarum, 9th edition. London: William Lee, 1670.

4 Bacon F. The new organon or: True directions concerning the interpretation of nature. Bennett J (editor), 2007. Available online at www.earlymoderntexts.com/assets/pdfs/bacon1620.pdf [Accessed 15 September 2015].

5 Gilbert W. On the magnet, magnetick bodies also, and on the great magnet the earth; a new physiology, demonstrated by many arguments \&\#38; experiments. Thompson S (translator). London: Chiswick Press, 1900.

6 Bacon F. The new organon. Cambridge texts in the history of philosophy. Jardine L and Silverthorne M (eds). Cambridge: Cambridge University Press, 2000.

7 Perry RB. Realms of value: A critique of human civilisation. New York: Greenwood Press, 1954.

8 Stroud B. The study of human nature and the subjectivity of value. The Tanner lectures on human values, delivered at the University of Buenos Aires, 7 June 1988. Available online at http://tannerlectures.utah.edu/_documents/a-to-z/s/stroud89.pdf [Accessed 15 September 2015].

9 Monastersky R. The human age. Nature 2015;519:144-7.

10 Mission and Public Affairs Council of the Church of England. Mitochondrial donation: A consultation on draft regulations to permit the use of new treatment techniques to prevent the transmission of a serious mitochondrial disease from mother to child. Available online at www.churchofengland.org/media/2156778/mitochondrial\%20 donation\%20consultation.pdf [Accessed 15 September 2015].

11 Knapton S. Three parent baby law is 'irresponsible' says Church of England ahead of vote. The Telegraph, 29 January 2015. Available online at www.telegraph.co.uk/news/science/11377992/Threeparent-baby-law-is-irresponsible-says-Church-of-England-aheadof-vote.html [Accessed 15 September 2015].

12 Royal Society and Royal Academy of Engineering. Shale gas extraction in the UK: a review of hydraulic fracturing. London: Royal Society and Royal Academy of Engineering, 2012. Available online at www.raeng.org.uk/publications/reports/shale-gas-extraction-inthe-uk [Accessed 16 September 2015].

13 Hume D. A treatise of human nature: being an attempt to introduce the experimental method of reasoning into moral subjects. London: printed for John Noon, 1739.

14 Douglas M. Risk and blame: Essays in cultural theory. London and New York: Routledge, 1992.

15 Cardis E, Howe G, Ron E et al. Cancer consequences of the Chernobyl accident: 20 years on. J Radiol Prot 2006;26(2):127-40.

16 Steinhauser G, Brandl A, Johnson TE. Comparison of the Chernobyl and Fukushima nuclear accidents: A review of the environmental impacts. Sci Total Environ 2014;470-471:800-817.

17 Beck U. Risk society: Towards a new modernity. Ritter M (translator). London: SAGE Publications, 1992.

18 Goldman M. Cancer risk of low-level exposure. Science 1996;271:1821-2.

19 Walport M, Craig C. Innovation: Managing Risk, Not Avoiding It. Annual Report of the Government Chief Scientific Adviser 2014. Available online at https://www.gov.uk/government/uploads/ system/uploads/attachment_data/file/381905/14-1190a-innovationmanaging-risk-report.pdf [Accessed 16 September 2015]. 